\title{
Pengaruh Tanggung Jawab Sosial Terhadap Manajemen Laba Dengan Kepemilikan Keluarga Sebagai Pemoderasi
}

\author{
Sukma Mardaning Poncowati ${ }^{1}$, Supatmi Supatmi ${ }^{2}$ \\ ${ }^{1}$ Universitas Kristen Satya Wacana, Salatiga, Indonesia \\ ${ }^{2}$ Universitas Kristen Satya Wacana, Salatiga, Indonesia
}

\section{ARTICLE INFO \\ JEL Classification: M14, Q56}

Key words:

Earnings management, Family ownership, Social responsibility

\begin{abstract}
Earning management practices are one of the many things that management can do in achieving company's goals or management's personal goals. Through earning management, the company can convey positive signals about the value and achievement of the company to the public. This study aimed to determine out how the impact of environmental aspects of Corporate Social Responsibility on earning management with family ownership as a moderation of causal relationships. This research was conducted at manufacturing companies in the consumer goods industry sector on the Indonesia Stock Exchange in 2018-2019. The sample selection in this study used purposive sampling method and obtained 43 sample companies using panel data regression analysis techniques for hypothesis testing and processed using Eviews 10. The results of this study indicate that the environmental aspects of Corporate Social Responsibility have a significant negative effect on firm value and risk management is proven to moderate partially the causal relationship.
\end{abstract}

\begin{abstract}
ABSTRAK
Praktik manajemen laba merupakan satu dari banyak hal yang dapat dilakukan manajemen dalam mencapai tujuan perusahaan maupun tujuan pribadi manajemen. Melalui manajemen laba, perusahaan dapat menyampaikan sinyal-sinyal positif tentang nilai dan pencapaian perusahaan kepada publik. Tujuan penelitian ini untuk mengetahui bagaimana pengaruh tanggung jawab sosial aspek lingkungan terhadap manajemen laba dengan kepemilikan keluarga sebagai moderasi hubungan kausal tersebut. Penelitian ini dilakukan pada perusahaan manufaktur sektor barang dan konsumsi yang terdaftar dalam Bursa Efek Indonesia pada tahun 2018-2019. Pemilihan sampel dalam penelitian ini menggunakan metode purposive sampling dan diperoleh 43 perusahaan sampel dengan menggunakan teknis analisis regresi data panel untuk pengujian hipotesis dan diolah menggunakan Eviews 10. Hasil penelitian ini menunjukkan tanggung jawab sosial aspek lingkungan berpengaruh negatif terhadap manajemen laba dan kepemilikan keluarga terbukti momedari secara parsial hubungan kausal tersebut.
\end{abstract}

\section{PENDAHULUAN}

Melalui laporan keuangan dapat dilihat baik atau buruknya kinerja keuangan sehingga manajemen dapat memiliki kebijaksanaan tertentu dalam mempengaruhi jumlah pendapatan (Kumala \& Siregar, 2019). Standar akuntansi memberikan kelonggaran bagi manajemen dalam memilih metode akuntansi untuk menyajikan laporan keuangan perusahaan (Perwitasari et al., 2013), sehingga melalui kelonggaran ini manajemen dapat memenuhi tujuan tertentu untuk kepentingan diri sendiri maupun kepentingan perusahaan. Pada praktiknya, manajemen melakukan berbagai hal dan cara dalam mencapai tujuan perusahaan maupun tujuan pribadi manajemen, salah satunya adalah manajemen laba atau earnings management. Sementara itu, terjadinya praktik manajemen laba memberikan informasi yang tidak simetris dengan keadaan perusahaan, sehingga informasi tersebut dapat merugikan pengguna

*Email Korespondensi: ${ }^{1}$ sukmardaa@gmail.com 
laporan keuangan (Kumala \& Siregar, 2019).

Salah satu fenomena manajemen laba di Indonesia adalah kasus pada PT Tiga Pilar Sejahtera Food Tbk (Grup AISA), dalam laporan Hasil Investigasi Berbasis Fakta PT Ernst \& Young (EY) ASIA telah melakukan penggelumbungan dana senilai $\mathrm{Rp} 4$ triliun, penggelembungan pendapatan senilai Rp 622 miliar dan penggelembungan lain senilai $\mathrm{Rp}$ 329 miliar. Selain itu, manajemen laba serupa juga dilakukan oleh Pertamina. Pertamina mencatat piutang atas pembayaran selisih harga sebesar Rp 41,6 triliun sebagai pendapatan. Piutang yang belum dibayarkan pemerintah tersebut merupakan kompensasi harga BBM pada tahun 2017 dan 2018 (Arieza, 2019).

Octavia (2017) menyatakan bahwa manajemen laba merupakan tindakan untuk mengelabui investor dalam rangka memenuhi target laba sehingga manajemen laba dinilai negatif. Oleh sebab itu, timbul program Corporate Social Responbility (CSR) yang dinilai dapat memberikan citra positif perusahaan. Swat et al. (2015) menyatakan bahwa strategi perusahaan yang mempertimbangkan faktor seperti kesehatan konsumen dan keamanan dalam penggunaan produk dapat mempengaruhi secara positif citra perusahaan dan kinerja perusahaan. Selain itu, perusahaan mulai menyadari CSR merupakan pokok lain dari strategi perusahaan. Perusahaan pada tahun 2019 semakin kian intens mengintegrasikan CSR ke dalam proses manajerial, pengambilan keputusan, dan strategi keseluruhan (Majalahcsr, 2019).

Kerusakan lingkungan dan pencemaran lingkungan dewasa ini menjadi perhatian secara global, banyak pihak-pihak yang mulai tergerak mengenai pentingnya kepedulian akan lingkungan. Berbagai lembaga peduli lingkungan hidup mulai bermunculan untuk melawan perusak lingkungan yang merusak lingkungan yang mengancam kelangsungan hidup (Christoforus, 2019). Begitu pula dengan beberapa perusahaan yang mulai menunjukkan kepeduliannya akan lingkungan hidup dan sekitar dalam program Corporate
Social Responsibility (CSR) dalam aspek lingkungan dengan mempunyai program untuk mengolah limbah pabrik yang berbahaya menjadi lebih ramah terhadap lingkungan (www.jateng.idntimes.com). Program mengenai CSR dalam aspek lingkungan ini hadir dari pemikiran bahwa perusahaan tidak lepas dari tanggung jawab atas lingkungan sekitar, tidak hanya berfokus pada kegiatan ekonomi seperti pendapatan dan laba, namun perlu mempertanggung jawabkan tindakan yang dilakukan pada lingkungan hidup, konsumen dan sekitar (Ibrahim et al., 2015). Selain itu, menurut Setyaningsih \& Asyik (2016) permasalahan lingkungan semakin diperhatikan baik oleh konsumen, investor dan pemerintah. Muncul berbagai kerusakan lingkungan akibat pencemaran limbah dan eksploitasi sumber daya alam tanpa diimbangi dengan perbaikan lingkungan, hal tersebut sangat merugikan lingkungan dan ekosistem.

Penelitian Muttakin et al. (2015) menyatakan adanya hubungan antara CSR dan earnings management pada perusahaan non-financial di Bangladesh 2005-2009. Penelitian tersebut mengungkapkan bahwa manajemen melakukan insentif untuk kepentingan diri sendiri serta menggunakan CSR untuk menutupi earnings management yang dilakukan. Selanjutnya, hal tersebut menunjukkan dugaan bahwa dilakukannya program CSR berpengaruh terhadap meningkatnya tindakan earnings management. Penelitian ini sejalan dengan hasil penelitian Santi \& Wardani (2018) yang menyatakan bahwa perusahaan dengan CSR yang tinggi cenderung mendapat kepercayaan publik yang tinggi. Kepercayaan publik tersebut digunakan untuk menutupi earnings management perusahaan. Namun, Salewski \& Zülch (2012) menyatakan bahwa perusahaan yang memiliki kepedulian terhadap lingkungan dan kepada stakeholder mereka, cenderung mengungkapkan informasi keuangan secara transparan dan memberikan laporan sesuai dengan keuangan mereka. Oleh karena itu, dengan adanya program CSR perusahaan semakin transparan terhadap 
kondisi keuangan dan meminimalisir tindakan earnings management. Penelitian tersebut didukung oleh Scholtens \& Kang (2012) yang menyatakan bahwa perusahaan di Asia dengan pengungkapan CSR relatif baik cenderung memiliki praktik earnings management yang kecil.

Penelitian sebelumnya oleh Kumala \& Siregar (2019) terhadap 105 perusahaan tambang milik keluarga yang terdaftar di Bursa Efek Indonesia (BEI) periode 2012-2014, menunjukkan bahwa pengungkapan CSR memiliki pengaruh negatif pada earnings management. Dengan menggunakan model cross-sectional versi Kothari et al. (2005) untuk mengukur earning management serta pedoman Global Reporting Initiative (GRI) G4 atau G3,1 dalam pengukuran CSR, family ownership ditemukan berpengaruh positif pada earnings management. Begitu juga dengan penelitian Scholtens \& Kang (2012) pada 139 perusahaan dalam 10 negara di Asia menyatakan bahwa CSR memiliki pengaruh negatif terhadap earnings managemet.

Sebaliknya, dalam penelitian MartínezFerrero et al. (2016) dan Muttakin et al. (2015) menyatakan bahwa CSR dapat berpengaruh positif terhadap earnings management. Martínez-Ferrero et al. (2016) melakukan penelitian pada perusahaaan non-financial yang terdaftar secara publik tahun 2006-2010, menyatakan bahwa CSR dapat digunakan oleh para manajer dalam memanipulasi laba untuk menghalangi pemegang saham bereaksi dalam kebijakan manajerial tersebut. Dengan pengukuran earnings management menggunakan Discretionary Accruals (DA) Modified Jones Model yang dikembangkan oleh Dechow et al. (1995) serta mengukur praktik CSR berdasarkan informasi CSR yang dikumpulkan dari database EIRIS. Hasil penelitian tersebut sejalan dengan hasil penelitian Muttakin et al. (2015) yang menunjukkan bahwa adanya hubungan positif antara tingkat pengungkapan CSR dengan manajemen laba. Penelitian tersebut dilakukan pada perusahaan non-financial yang terdaftar dalam Dhaka Stock Exchange (DSE) Bangladesh tahun 2005-2009.
Hubungan antara CSR dengan manajemen laba tidak lepas dari struktur kepemilikan dalam perusahaan. Liu et al. (2017) menyatakan bahwa perusahaan kepemilikan keluarga cenderung memiliki kinerja CSR yang lebih tinggi sehingga dapat membantu mereka untuk mempertahankan legitimasi dan socioemotional wealth. Legitimasi tersebutlah yang digunakan untuk menyamarkan tindakan earnings management. Penelitian tersebut didukung oleh Campopiano \& de Massis (2015) yang menyatakan bahwa keterlibatan kepemilikan keluarga memiliki peran yang penting terhadap pengungkapan CSR karena dapat menjaga nama baik perusahaan terhadap publik. Di sisi lain, dari sudut pandang teori agensi manajer sebagai agent dapat memutuskan tindakan manajemen laba untuk mengelabui investor dan memaksimalkan tujuan tertentu (Octavia, 2017). Oleh karena itu, kepemilikan keluarga diharapkan dapat menjadi faktor yang memoderasi hubungan antara CSR dengan earnings management. Sehubungan dengan itu, Kumala \& Siregar (2019) juga menyatakan bahwa kepemilikan keluarga memperkuat hubungan negatif antara CSR dan manajemen laba.

Penelitian ini bertujuan untuk menyediakan bukti empiris pengaruh CSR terhadap tindakan manajemen laba dengan kepemilikan keluarga sebagai pemoderasi. Penelitian ini berfokus pada aspek lingkungan dikarenakan pada tahun 2019 Kementerian Lingkungan Hidup dan Kehutanan (KLHK) menyatakan bahwa hanya $29,15 \%$ dari total keseluruhan industri yang dinilai melalui Proper dan dinyatakan layak dalam kepatuhan pengelolaan lingkungan (Nurcaya, 2020). Penelitian ini menggunakan sampel penelitian perusahaan manufaktur sektor industri barang konsumsi yang terdaftar Bursa Efek Indonesia periode 2018-2019. Perusahaan manufaktur dipilih karena kepatuhan sektor manufaktur dalam pengelolaan lingkungan dinilai masih sangat rendah oleh Kementerian Lingkungan Hidup dan Kehutanan (KLHK) (Nurcaya, 2020). Selain itu, Wirawan et al. (2020) menyatakan bahwa sektor manufaktur 
seperti industri logam, kimia, kertas dan farmasi merupakan industri sensitif yang berdampak langsung terhadap lingkungan. Pengukuran CSR yang akan diteliti diukur menggunakan Global Reporting Initiative (GRI) terbaru yaitu GRI Standar khususnya mengenai aspek lingkungan, indikator ini berfokus pada kepedulian perusahaan terhadap lingkungan sekitar dan ekosistem.

Hasil penelitian ini dapat menambah hasil empiris untuk aplikasi teori stakeholder pada perusahaan sektor manufaktur milik keluarga di negara berkembang khususnya Indonesia. Selanjutnya, dapat menjadi aspek yang dapat dipertimbangkan oleh perusahaan dalam melakukan program CSR dalam aspek lingkungan khususnya pada perusahaan keluarga. Di samping itu, dapat menjadi pertimbangan bagi investor dalam pengambilan keputusan investasi, serta menjadi pertimbangan dalam menetapkan kebijakan khususnya aspek CSR oleh Otoritas Jasa Keuangan (OJK).

\section{TELAAH \\ TEORI PENGEMBANGAN HIPOTESIS}

DAN

Freeman (1984) mendefinisikan teori stakeholder sebagai teori mengenai kepada siapa saja pertanggung jawaban manajer dalam menjalankan aktivitas organisasi. Teori stakeholder menunjukan bahwa kebijakan pengungkapan perusahaan adalah alat untuk mengelola informasi yang nantinya akan dipertanggung jawabkan kepada stakeholders (Muttakin et al., 2015). Oleh karena itu, dengan adanya pengungkapan informasi tersebut diharapkan dapat memenuhi kebutuhan informasi para stakeholder dan dapat mendukung keberlangsungan perusahaan. Teori stakeholder memberikan penjelasan mengapa perusahaan melibatkan diri dalam kegiatan tanggung jawab sosial dengan mengakui pentingnya keterlibatan para stakeholder (Gras-Gil et al., 2016).

Manajemen laba merupakan tindakan manajemen dalam memilih kebijakan akuntansi dalam rangka memaksimalkan utilitas dan nilai organisasi. Manajemen laba adalah tindakan oportunistis manajer dalam rangka mengelabui investor dan meningkatkan kesejahteraannya karena memegang informasi yang lebih banyak dibandingkan pihak lain untuk mewujudkan kepentingan pribadi (Scott, 2012). Tindakan mengelabui tersebut dinilai negatif dan dapat merugikan para pemangku kepentingan termasuk para pengguna laporan keuangan. Perusahaan melakukan manajemen laba dalam rangka untuk mempengaruhi keputusan para pemegang kepentingan (Scholtens \& Kang, 2012).

Melalui manajemen laba, perusahaan dapat menyampaikan sinyal-sinyal positif tentang nilai dan pencapaian perusahaan kepada publik (Boermawan \& Siregar, 2013). Melalui sinyal-sinyal positif tersebut dapat mendukung keberlangsungan perusahaan dan menarik minat para investor ataupun kreditor. Penelitian Healy \& Wahlen (1999) menemukan bahwa faktor yang mempengaruhi manajemen laba, termasuk untuk meningkatkan intensif manajemen, untuk menghindari intervensi regulator serta untuk mempengaruhi persepsi pasar modal. Pandangan tersebut sejalan dengan Sokarina (2012) yang menyatakan bahwa manajemen laba dilakukan sebagai tindakan yang disengaja dalam laporan keuangan untuk kepentingan pribadi.

Program Corporate Social Responsibility (CSR) atau tanggung jawab sosial merupakan suatu kewajiban bagi perusahaan yang telah diatur dalam Undang-undang No. 40 Tahun 2007 tentang perseroan terbatas dan Peraturan Pemerintah tahun 2012. Program tanggung jawab sosial ini dilakukan dengan memperhatikan setiap operasional perusahaan agar dapat berdampak nyata terhadap kualitas lingkungan, hidup, masyarakat dan sekitar (Ibrahim et al., 2015). Tanggung jawab sosial berkaitan dengan aspek etika dan moral tentang pengambilan keputusan perusahaan dan perilaku, dengan membahas masalah kompleks seperti perlindungan lingkungan, manajemen sumber daya manusia, kesehatan dan keselamatan kerja, hubungan masyarakat setempat, dan hubungan dengan supplier dan pelanggan (Gras-Gil et al., 2016). Dengan adanya program tanggung jawab sosial dalam 
aspek lingkungan menyampaikan bagaimana tindakan perusahaan untuk ekosistem dan lingkungan hayati, tidak hanya berfokus pada laba dan kepentingan ekonomi saja.

Melalui program tanggung jawab sosial aspek lingkungan merupakan bentuk pertanggungjawaban sesuai dengan batas norma masyarakat dan lingkungan. Melalui pengungkapan tanggung jawab sosial menjadi tanda yang diberikan manajemen kepada seluruh stakeholder termasuk calon investor mengenai prospek perusahaan di masa depan serta menunjukkan nilai lebih yang dimiliki oleh perusahaan atas kepeduliannya terhadap dampak ekonomi, sosial dan lingkungan sekitar yang timbul dari aktivitas perusahaan tersebut (Swat et al., 2015). Pengungkapan tanggung jawab sosial aspek lingkungan dapat diukur berdasarkan indikator pengungkapan dalam Global Reporting Initiative (GRI) terbaru yaitu GRI Standar yang terdiri dari 8 aspek dengan 32 pengungkapan.

Alonso \& Austin (2016) mendefinisikan sebuah firma keluarga sebagai sebuah bisnis yang dikelola atau diatur dengan tujuan untuk membentuk dan mencapai visi yang dipegang oleh keluarga dengan berkelanjutan dan melalui generasi dari keluarga yang sama. Perusahaan kepemilikan keluarga dicirikan oleh konsentrasi kepemilikan keluarga yang tinggi, sering menjadi mayoritas pemegang saham dan dapat melakukan berbagai fungsi dalam pengelolaan perusahaan (MartínezFerrero et al., 2016). Peran penting kepemilikan keluarga dalam perusahaan adalah menjaga nama baik keluarga dimata publik dengan melakukan strategi pengungkapan tanggung jawab sosial perusahaan dalam bentuk laporan ke publik. Pengawasan dan pengendalian atas kebijaksanaan manajerial sangat dipengaruhi oleh struktur kepemilikan, yang mana dalam perusahaan Indonesia didominasi oleh kepemilikan keluarga (Kumala \& Siregar, 2019).

\subsection{Pengaruh Tanggung Jawab Sosial Terhadap Manajemen Laba} Stakeholder memiliki peran penting dalam keputusan dan kegiatan perusahaan. Melalui pengungkapan informasi inilah bentuk interpretasi tanggung jawab perusahaan terhadap stakeholder (Muttakin et al., 2015). Dengan adanya pengungkapan informasi melalui Corporate Sosial Responbility (CSR) stakeholder akan disuguhkan dengan laporan keuangan yang transparan dengan meminimalkan praktik manajemen laba (Kumala \& Siregar, 2019). Oleh karena itu, perusahaan dengan kepedulian akan pengungkapan dan kepedulian terhadap stakeholder akan lebih meminimalisir adanya manajemen laba. Stakeholder tidak hanya akan melihat perusahaan dalam aspek kinerja perusahaan saja, namun perlu melihat perusahaan dalam respons terhadap lingkungan sekitar. Hal tersebut sejalan dengan Villarón-Peramato et al. (2018) yang menyatakan bahwa manajer yang kuat lebih cenderung berinvestasi dalam CSR untuk memperkuat kepercayaan mereka di mata para pemangku kepentingan.

Penelitian terdahulu oleh Chih et al. (2008) menunjukkan bahwa perusahaan yang lebih berkomitmen dalam program CSR memberikan pengungkapan keuangan yang lebih luas dan kurang terlibat dalam manajemen laba. Hal tersebut sejalan dengan Kim et al. (2012) yang menemukan bahwa perusahaan yang bertanggung jawab secara sosial dan lingkungan cenderung tidak terlibat dalam manajemen laba untuk memanipulasi kegiatan operasional. Selain itu, pada Peraturan Otoritas Jasa Keuangan No. 29 tahun 2016 menyatakan bahwa mewajibkan perusahaan untuk mengungkapkan bentuk tanggung jawab sosial dan lingkungan dalam laporan tahunan sehingga belum tentu perusahaan dengan pengungkapan CSR berhubungan secara langsung dengan strategi dalam menutupi manajemen laba. Dengan masih banyaknya pelanggaran perusahaan terhadap lingkungan maka kesadaran perusahaan terhadap lingkungan masih perlu diuji untuk melihat motivasi perusahaan melakukan terhadap program CSR (Dianawati, 2017). Berdasarkan argumen yang telah dipaparkan maka dapat dirumuskan 
hipotesis satu :

$\mathrm{H}_{1}$ : Tanggung jawab sosial berpengaruh negatif terhadap manajemen laba.

\subsection{Pengaruh Tanggung Jawab Sosial Terhadap Manajemen Laba yang Dimodeari Kepemilikan Keluarga \\ Pada sebagian besar negara, keluarga} adalah jenis pemegang saham pengendali yang paling umum. Keluarga pemegang saham memiliki akses yang lebih luas terhadap informasi daripada pemegang saham minoritas (Kumala \& Siregar, 2019). Diharapkan bahwa aspek kepemilikan keluarga akan mengurangi probabilitas adanya kebijaksanaan manajerial yang menyimpang (Martínez-Ferrero et al., 2016). Kemudian, dalam perusahaan yang dicirikan oleh tingkat kepemilikan yang tinggi di tangan keluarga, pemegang saham memiliki lebih banyak akses ke informasi yang memungkinkan mereka untuk memeriksa dan mengawasi keputusan manajerial.

Campopiano \& de Massis (2015) menyatakan bahwa kepemilikan keluarga memiliki peran penting dalam menjaga nama baik perusahaan dengan pengungkapan tanggung jawab sosial dan lingkungan perusahaan kepada publik dalam bentuk laporan tahunan. Muhajir Haris \& Priyo Purnomo (2016) pun menyatakan bahwa perusahaan yang baik tidak hanya berfokus terhadap laba, namun memiliki kepedulian terhadap lingkungan. Oleh karena itu diharapkan, peran kepemilikan keluarga akan meminimalisir tindakan manajemen laba untuk tetap menjaga nama baik perusahaan dan lebih meningkatkan kepercayaan publik dengan mengungkapkan berbagai program CSR yang dilakukan perusahaan. Selain itu, Kumala \& Siregar (2019) menyatakan bahwa semakin tinggi kepemilikan keluarga, semakin signifikan pula hubungan negatif antara tanggung jawab sosial dengan manajemen laba. Berdasarkan argumen yang telah dipaparkan maka dapat dirumuskan hipotesis dua:

$\mathrm{H}_{2}$ : Kepemilikan keluarga memperkuat pengaruh tanggung jawab sosial terhadap manajemen laba

\section{METODE PENELITIAN}

Populasi dalam penelitian ini adalah seluruh perusahaan manufaktur sektor industri barang konsumsi yang terdaftar di Bursa Efek Indonesia (BEI) selama tahun 20182019. Metode yang digunakan dalam pemilihan sampel penelitian yaitu purposive sampling dengan teknik judgement sampling.

Tabel 3.1

Kriteria Purposive Sampling Penelitian

\begin{tabular}{|c|c|}
\hline Kriteria Sampel & Jumlah Sampel \\
\hline $\begin{array}{l}\text { Perusahaan manufaktur sektor } \\
\text { industri barang konsumsi } \\
\text { periode 2018-2019. }\end{array}$ & 59 \\
\hline $\begin{array}{l}\text { Perusahaan manufaktur sektor } \\
\text { industri barang konsumsi yang } \\
\text { tidak menerbitkan laporan } \\
\text { tahunan periode 2018-2019. }\end{array}$ & (8) \\
\hline $\begin{array}{l}\text { Tanggal pelaporan laporan } \\
\text { keuangan yang diterbitkan tidak } \\
\text { berakhir pada tanggal } 31 \\
\text { Desember. }\end{array}$ & (2) \\
\hline $\begin{array}{l}\text { Perusahaan manufaktur sektor } \\
\text { industri barang konsumsi yang }\end{array}$ & (6) \\
\hline
\end{tabular}




\begin{tabular}{l}
\hline tidak mengungkapkan Corporate \\
Social Responbility (CSR) \\
khususnya aspek lingkungan \\
dalam laporan tahunan. \\
\hline Total Sampel
\end{tabular}

Sumber : Data yang diolah, 2021

Jenis data yang digunakan dalam penelitian ini adalah data sekunder yang berupa laporan keuangan tahunan perusahaan yang diperoleh melalui www.idx.co.id. Metode pengumpulan data penelitian terkait diperoleh dengan mencari secara langsung dari laporan keuangan dan catatan-catatan dalam laporan keuangan.

Variabel dependen dalam penelitian ini ialah manajemen laba. Manajemen laba sebagai diproksikan dengan discretionary accrual dengan menggunakan modified jones model karena dianggap lebih baik diantara model lain serta ini adalah metode yang paling banyak diterima dan digunakan dalam literatur. Model perhitungannya sebagai berikut :

$\mathbf{T A}_{\text {it }}$

$$
=\mathrm{NI}_{\mathrm{it}}-\mathrm{OCF}_{\mathrm{it}}
$$

$$
\begin{aligned}
& \mathrm{TA}_{\mathrm{it}} / \mathrm{A}_{\mathrm{it}-1}=\mathrm{a}_{1}\left(1 / \mathrm{A}_{\mathrm{it}}\right)+\mathrm{a}_{2}\left(\Delta \mathrm{REV}_{\mathrm{it}} / \mathrm{A}_{\mathrm{it}-1}\right)+\mathrm{a} 3 \\
& \left(\mathrm{PPE}_{\mathrm{it}} / \mathrm{A}_{\mathrm{it}-1}\right)+\varepsilon_{\mathrm{it}}
\end{aligned}
$$

Kedua persamaan regresi tersebut menunjukkan bahwa NDACC dihitung dengan memasukkan kembali koefisien $a_{1}, a_{2}$, dan $\alpha_{3}$ ke persamaan sebagai berikut:

\section{NDACC $=a_{1}\left(1 / A_{i t}\right)+\alpha 2(\triangle R E V / A i t-1-$ $\Delta$ REC/Ait-1) $+\alpha_{3}\left(P^{P} E_{i t} / A_{i t-1}\right)$}

Sehingga timbul persamaan dalam menghitung discretionary accruals sebagai berikut :

$$
\mathrm{DA}_{\mathrm{it}} \quad=\mathrm{TA}_{\mathrm{it}} / \mathrm{A}_{\mathrm{it}-1}-\mathrm{NDA}_{\mathrm{it}}
$$

Keterangan :

$\mathrm{TA}_{\mathrm{it}}=$ Total akrual perusahaan $i$ pada tahun $t$

$\mathrm{NI}_{\text {it }}=$ Laba bersih (Net Income) perusahaan $i$ pada tahun $t$
$\mathrm{OCF}_{\text {it }}=$ Kas dari operasi (Operation Cash Flow) perusahan $i$ pada tahun $t$

$\mathrm{A}_{\mathrm{it}-1} \quad=$ Aset perusahaan $i$ pada tahun $t$

$\Delta \mathrm{REV}_{\mathrm{it}}=$ Pendapatan perusahaan $i$ pada tahun $t$ dikurangi pendapatan pada tahun $t$ 1

$\triangle \mathrm{REC}_{\mathrm{it}}=$ Piutang perusahaan $I$ pada tahun $t$ dikurangi pendapatan pada tahun $\mathrm{t}-1$

$\mathrm{PPE}_{\mathrm{it}}=$ Piutang perusahaan perusahaan $i$ pada tahun $t$ dikurangi pendapatan pada tahun $t-1$

$\varepsilon_{\mathrm{it}} \quad=$ Error term perusahaan $i$ pada tahun $t$

DA $_{\text {it }}=$ Discretionary accruals perusahaan $i$ pada tahun $t$

$\mathrm{NDA}_{i t}=$ Non-discretionary accruals perusahaan $i$ pada tahun $t$

Tanggung jawab sosial sebagai variabel independen diukur menggunakan Corporate Social Responsibility Index (CSRI) yang mengacu pada pedoman instrumen Global Instrument Initiative (GRI) versi GRI Standard. Kategori pengungkapan yang digunakan yaitu lingkungan yang terdiri dari 8 aspek dengan 32 item pengungkapan. Pengukuran variabel CSR diukur dengan variabel dummy, bernilai 1 jika kategori informasi diungkapkan dalam laporan tahunan, dan nilai 0 jika kategori informasi tidak diungkapkan dalam laporan keuangan. Rumus dalam menghitung CSR dituliskan sebagai berikut :

$\operatorname{CSRI}_{\mathrm{i}}=\frac{\sum X k i}{N i}$

Keterangan :

$\mathrm{CSRI}_{\mathrm{i}}=$ Corporate Sociel Responsibility Index perusahaan $i$

$\sum \mathrm{Xki}=$ total dari kategori informasi CSR yang diungkapkan dalam laporan tahunan

$\mathrm{Ni}=$ jumlah item untuk perusahaan $i$ 
Kemudian, Kusuma (2018) menyatakan bahwa kepemilikan keluarga dalam perusahaan setidaknya harus memiliki 20\% bagian dari perusahaan tersebut. Dengan begitu, kepemilikan keluarga sebagai variabel moderasi diukur dengan variabel dummy, bernilai 1 jika ada kepemilikan keluarga lebih dari $20 \%$ dan bernilai 0 jika kepemilikan keluarga kurang dari $20 \%$.

Pengujian hipotesis penelitian ini menggunakan regresi data panel EGLS (Crosssection weights) yang diolah menggunakan Eviews 10. Panel data memungkinkan mempelajari lebih kompleks mengenai perilaku yang ada dalam model sehingga pengujian data panel tidak memerlukan uji asumsi klasik (Gujarati, 2012). Lebih lanjut dijelaskan bahwa dalam model ini dilakukan pembobotan yang bertujuan untuk mengurangi heterogenitas antar unit crosssection. Dengan begitu, penggunaan model ini tepat untuk melihat perilaku data dari setiap variabel sehingga data lebih dinamis dalam menginterpretasikan data yang ada. Dengan begitu, persamaan regresi untuk pengujian hipotesis pertama $\left(\mathbf{H}_{1}\right)$ dalam penelitian ini sebagai berikut :

$$
\mathrm{EM}_{\mathrm{t}}=\beta_{\mathrm{o}}+\beta_{1} \mathrm{CSR}_{\mathrm{it}}+\beta_{3} \mathrm{LEV}_{\mathrm{it}}+\beta_{4} \mathrm{FIRM}_{\mathrm{it}}+€_{\mathrm{it}}
$$

Sedangkan persamaan regresi untuk pengujian hipotesis kedua $\left(\mathbf{H}_{2}\right)$ dalam penelitian ini sebagai berikut :

$$
\begin{aligned}
\mathrm{EM}_{\mathrm{t}}= & \beta \mathrm{o}+\beta_{1} \mathrm{CSR}_{\mathrm{t}}+\beta_{2} \mathrm{FAM}_{\mathrm{it}}+\beta_{3} \mathrm{CSR}_{\mathrm{it}} * \\
& \text { FAM }_{\mathrm{it}}+\beta_{4} \mathrm{LEV}_{\mathrm{it}}+\beta_{5} \mathrm{FIRM}_{\mathrm{it}}+\epsilon_{\mathrm{it}}
\end{aligned}
$$

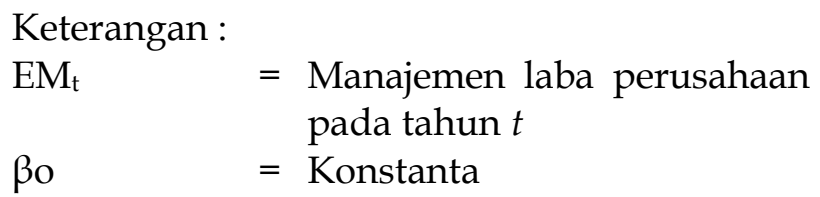

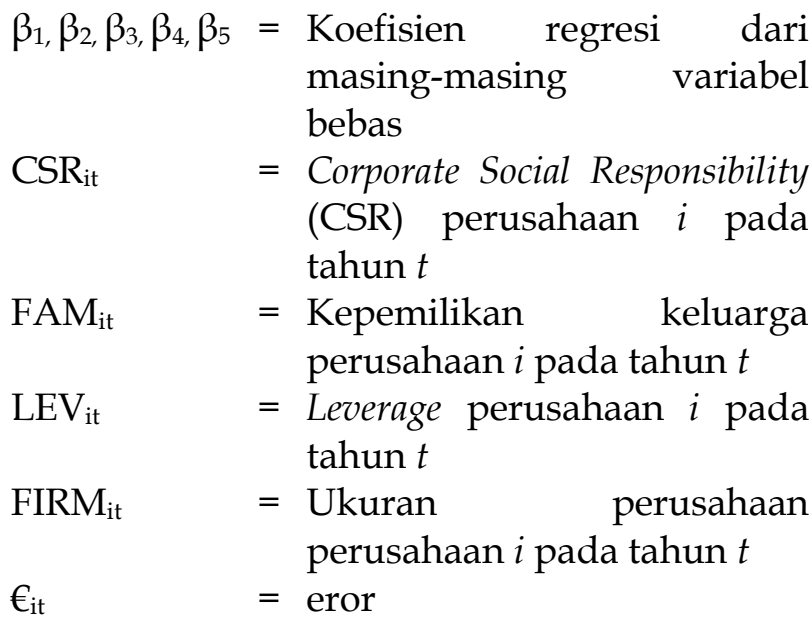

Penerimaan hipotesis pertama, yaitu bahwa tanggung jawab sosial berpengaruh negatif terhadap manajemen laba, menggunakan tingkat signifikan 5\% dengan hipotesis statistik sebagai berikut:

Ho: $\beta_{1} \geq 0$

Ha : $\beta_{1}<0$

Penerimaan hipotesis kedua, yaitu kepemilikan keluarga memperkuat pengaruh tanggung jawab sosial terhadap manajemen laba menggunakan tingkat signifikan 5\% dengan hipotesis statistik sebagai berikut:

Ho: $\beta_{3} \geq 0$

Ha : $\beta_{3}<0$

Selain itu, penerimaan hipotesis kedua juga akan dilihat dari nilai adjusted $R^{2}$ pengujian 2 (dengan moderasi) harus lebih besar dari nilai adjusted $R^{2}$ pengujian 1 (tanpa moderasi).

\section{HASIL DAN PEMBAHASAN}

Analisis statistik deskriptif mendeskripsikan mengenai ringkasan persebaran nilai minimal, nilai maksimal, mean dan standar deviasi dari masing-masing variabel. Berikut ini merupakan gambaran dari persebaran data seluruh variabel: 
Tabel 4. 1

Hasil Deskriptif Statistik

\begin{tabular}{llcccc}
\hline $\begin{array}{c}\text { Variabel } \\
\text { Penelitian }\end{array}$ & N & Min & Max & Mean & Std. Deviation \\
\hline EM & 86 & $-0,050$ & 0,042 & 0,002 & 0,011 \\
CSR & 86 & 0,090 & 0,750 & 0,380 & 0,175 \\
LEV & 86 & $-2,130$ & 3,340 & 0,830 & 0,798 \\
SIZE & 86 & 25,75 & 32,20 & 28,58 & 1,61 \\
\hline
\end{tabular}

Sumber : Data yang diolah, 2021

\begin{tabular}{ccc}
\hline Variabel penelitian & Jumlah & Proporsi \\
\hline Kepemilikan Keluarga (FAM) & & \\
Kepemilikan Keluarga lebih dari 20\% (1) & 32 & $74 \%$ \\
Kepemilikan Keluarga kurang dari 20\% (0) & 11 & $26 \%$ \\
\hline
\end{tabular}

Keterangan :

EM: Earnings Management (Manajemen Laba); CSR; Tanggung Jawab Sosial; FAM: 1 jika Kepemilikan Keluarga lebih dari $20 \%$ dan 0 jika kebalikannya; LEV: Leverage; SIZE: Ukuran Perusahaan

Sumber : Data yang diolah, 2021

Berdasarkan tabel $4.1 \mathrm{di}$ atas, kolom $\mathrm{N}$ menjelaskan 93 data observasi yang digunakan dalam penelitian. Manajemen laba (EM) sebagai variabel dependen memiliki nilai ratarata sebesar 0,002 yang artinya hanya sebagian kecil perusahaan manufaktur sektor barang dan konsumsi yang terdeteksi melakukan praktik manajemen laba. Besaran nilai standar deviasi manajemen laba ialah 0,011 dimana lebih tinggi dibanding dengan nilai rata-rata yang artinya variasi dari manajemen laba relatif beragam. Nilai terendah manajemen laba sebesar -0,050 dimiliki oleh PT Tiga Pilar Sejahtera Food Tbk (AISA) untuk periode 2018 sedangkan nilai maksimum sebesar 0,042 dimiliki oleh PT Wahana Interfood Nusantara Tbk (COCO) pada periode 2018.

Sebagai variabel independen, tanggung jawab sosial (CSR) aspek lingkungan memiliki rata-rata sebesar 0,38 yang artinya praktik pengungkapan tanggung jawab sosial aspek lingkungan pada perusahaan manufaktur sektor barang dan konsumsi sebesar 38\% dari seluruh poin pengungkapan, yaitu 12 poin dari 32 kriteria pengungkapan tanggung jawab sosial aspek lingkungan. Hal ini menunjukkan masih cukup rendahnya pengungkapan tanggung jawab sosial dalam aspek lingkungan yang dilakukan oleh perusahaan manufaktur barang dan konsumsi. Data dari variabel tanggung jawab sosial aspek lingkungan tidak bervariasi dan relatif sama dikarenakan nilai standar deviasi sebesar 0,175 lebih kecil dari rata-rata tanggung jawab sosial aspek lingkungan. Besaran nilai terendah dari variabel tanggung jawab sosial sebesar 0,09 yang dimiliki oleh PT Wahana Interfood Nusantara Tbk untuk tahun 2018 dan 2019, serta untuk nilai tertinggi sebesar 0,75 dimiliki oleh Indofood Sukses Makmur Tbk pada tahun 2019.

Kepemilikan keluarga (FAM) sebagai variabel moderasi memiliki proporsi sebanyak $74 \%$ untuk kepemilikan keluarga lebih dari $20 \%$ dari seluruh sampel perusahaan manufaktur sektor barang dan konsumsi, yang artinya terdapat 32 perusahaan dari total 43 total sampel perusahaan manufaktur sektor barang dan konsumsi dimiliki oleh keluarga. Hal ini menunjukkan banyaknya perusahaan dengan kepemilikan keluarga mendominasi dalam industri manufaktur barang dan konsumsi. Kemudian, proporsi kepemilikan keluarga kurang dari 20\% sebesar 26\% yang artinya hanya 11 perusahaan dari seluruh total sampel perusahaan manufaktur sektor barang dan konsumsi yang tidak dimiliki oleh keluarga. Melalui hasil ini, dapat disimpulkan 
bahwa dalam kurun waktu 2018-2019 perusahaan kepemilikan keluarga mendominasi perusahaan industri manufaktur sektor barang dan konsumsi yang terdaftar dalam BEI.

Terdapat variabel leverage (LEV) dan ukuran perusahaan (SIZE) sebagai variabel kontrol. Nilai rata-rata dari leverage yang diproksikan dengan DER adalah sebesar 0,830 yang memiliki arti bahwa perusahaan memiliki hutang sebesar $83 \%$ dari total modalnya yang dapat dijadikan jaminan atas seluruh hutang yang dimiliki perusahaan. Sedangkan besaran nilai rata-rata ukuran perusahaan adalah sebesar 28,58.

Hasil dari pengujian hipotesis dijabarkan menjadi dua bagian, yaitu hasil analisis data panel EGLS (Cross-section weights) tanpa moderasi (model 1) dan hasil analisis data panel EGLS (Cross-section weights) dengan moderasi (model 2) yang dijabarkan pada tabel 4.2 sebagai berikut :

Tabel 4.2

Hasil Pengujian Hipotesis

\begin{tabular}{|c|c|c|c|c|c|c|}
\hline \multirow{3}{*}{ Variabel } & \multicolumn{6}{|c|}{ Manajemen Laba (EM) } \\
\hline & \multicolumn{4}{|c|}{ Model 1} & \multicolumn{2}{|c|}{ Model 2} \\
\hline & $\begin{array}{c}\text { Koefisien } \\
\text { Regresi }\end{array}$ & t-Statistik & Prob & $\begin{array}{c}\text { Koefisien } \\
\text { Regresi }\end{array}$ & t-Statistik & Prob \\
\hline Konstanta & 0,012 & 2,467 & 0,0157 & 0,021 & 4,705 & 0,0000 \\
\hline CSR & $-0,008$ & $-4,380$ & 0,0000 & $-0,023$ & $-6,863$ & 0,0000 \\
\hline FAM & & & & $-0,008$ & $-4,306$ & 0,0000 \\
\hline CSR ${ }^{*}$ FAM & & & & 0,020 & 5,014 & 0,0000 \\
\hline LEV & 0,002 & 3,456 & 0,0009 & 0,003 & 3,570 & 0,0006 \\
\hline SIZE & $-0,000$ & $-1,706$ & 0,0917 & $-0,000$ & $-2,663$ & 0,0094 \\
\hline $\mathrm{R}^{2}$ & 0,30 & & & 0,52 & & \\
\hline Adjusted $\mathrm{R}^{2}$ & 0,27 & & & 0,49 & & \\
\hline F-statistic & 11,37 & & 0,0000 & 17,08 & & 0,0000 \\
\hline
\end{tabular}

Keterangan :

EM: Earnings Management (Manajemen Laba); CSR; Tanggung Jawab Sosial; FAM: 1 jika Kepemilikan Keluarga lebih dari $20 \%$ dan 0 jika kebalikannya; LEV: Leverage; SIZE: Ukuran Perusahaan

Sumber : Data yang diolah, 2021

Berdasarkan hasil analisis data panel yang dilakukan dalam Tabel 4.2, nilai Adjusted $R^{2}$ untuk model 1 adalah 0,27. Hal ini berarti bahwa variabel independen tanggung jawab sosial, leverage serta ukuran perusahaan mampu mempengaruhi variabel dependen yaitu manajemen laba sebesar $27 \%$ dan sisanya senilai $77 \%$ manajemen laba dipengaruhi oleh faktor-faktor di luar model. Sementara itu, Adjusted $R^{2}$ pada model 2 memiliki nilai sebesar 0,47. Hal ini mengindikasi bahwa $47 \%$ variabel manajemen laba dapat dipengaruhi oleh seluruh variabel independen, yaitu tanggung jawab sosial, kepemilikan keluarga, interaksi antara tanggung jawab sosial dengan kepemilikan keluarga serta leverage dan ukuran perusahaan, dengan nilai sisa sebanyak 53\% dipengaruhi oleh faktor-faktor di luar model yang telah diuji. Kemudian, pada Tabel 3 diperoleh hasil nilai F statistik dengan nilai signifikansi kurang dari 0,05, yang artinya menunjukkan kelayakan model yang ada untuk ditetiliti (goodness of fit). Hal ini menunjukkan secara simultan variabel independen berpengaruh signifikan terhadap variabel dependen. Melalui hasil dari Adjusted $R^{2}$ serta $\mathrm{F}$ 
statistik, dapat disimpulkan bahwa secara statistik model penelitian ini layak untuk digunakan dan pengujian hipotesis lebih lanjut.

Hasil analisis dengan uji statistik $t$ dalam Tabel 4.2 diperoleh informasi nilai negatif koefisien regresi tanggung jawab sosial dengan tingkat signifikansi kurang dari 0,05. Hal ini menunjukkan tanggung jawab sosial aspek lingkungan berpengaruh negatif terhadap manajemen laba. Dengan demikian, H1 terdukung. Melalui hasil uji statistik $t$ pula dapat diperoleh informasi nilai koefisien regresi dari interaksi tanggung jawab sosial dengan kepemilikan keluarga sebagai variabel moderasi mengarah pada hasil positif dengan tingkat signifikansi kurang dari 0,05. Selanjutnya, nilai Adjusted $R^{2}$ pada tabel 4 dari model 2 (dengan moderasi) sebesar 0,49 menunjukkan nilai yang lebih besar dari Adjusted $R^{2}$ model 1 (tanpa moderasi) dengan nilai 0,27 sehingga hal ini menunjukkan kepemilikan keluarga mampu memperkuat pengaruh negatif tanggung jawab sosial terhadap manajemen laba. Dengan demikian $\mathrm{H} 2$ terdukung. Kepemilikan keluarga memoderasi hubungan kausal tersebut tidak secara full moderating melainkan secara parsial, karena dalam model 2 (dengan moderasi) menunjukkan tanggung jawab sosial aspek lingkungan masih pengaruh signifikan terhadap manajemen laba.

Tabel 4.2 di atas juga menunjukkan manajemen laba dapat dipengaruhi variabel lain. Pada model 1, tingkat leverage ditemukan berpengaruh positif signifikan terhadap nilai perusahaan sedangkan ukuran perusahaan terbukti berpengaruh negatif terhadap nilai perusahaan. Kemudian pada model 2, menunjukkan bahwa kepemilikan keluarga dan ukuran perusahaan pengaruh negative signifikan terhadap manajemen laba, sedangkan untuk variabel leverage berpengaruh positif signifikan terhadap manajemen laba.

\subsection{Pembahasan Pengaruh Tanggung Jawab Sosial terhadap Manajemen Laba}

Hasil pengujian diperoleh bahwa tanggung jawab sosial aspek lingkungan secara statistik memiliki pengaruh negatif yang signifikan terhadap manajemen laba. Hal ini menunjukkan bahwa semakin tinggi praktik pengungkapan tanggung jawab sosial aspek lingkungan, semakin rendah adanya praktik manajemen laba yang dilakukan perusahaan manufaktur sektor barang dan konsumsi. Hal ini sejalan dengan teori stakeholder yang menyatakan bahwa dengan adanya pengungkapan informasi melalui CSR, stakeholder akan disuguhkan dengan laporan keuangan yang transparan dengan minimnya praktik manajemen laba (Kumala \& Siregar, 2019). Dengan begitu, melalui pengungkapan CSR inilah merupakan bentuk implementasi tanggung jawab perusahaan terhadap pemangku kepentingan. Hasil penelitian ini juga membuktikan bahwa pengungkapan CSR dilakukan untuk dapat memenuhi Peraturan Otoritas Jasa Keuangan No. 29 tahun 2016 yang menyatakan bahwa mewajibkan perusahaan untuk mengungkapkan bentuk tanggung jawab sosial dan lingkungan dalam laporan tahunan. Oleh karena itu, dengan adanya pengungkapan CSR belum tentu perusahaan tersebut melakukan praktik manajemen laba namun hanya sebagai bentuk kepatuhan dalam memenuhi peraturan.

Hasil penelitian sejalan dengan Kim et al. (2012) yang menyatakan bahwa perusahaan yang bertanggung jawab secara sosial dan lingkungan cenderung tidak terlibat dalam manajemen laba untuk memanipulasi kegiatan operasional. Begitu pula dengan hasil penelitian oleh Salewski \& Zülch (2012), Scholtens \& Kang (2012) dan Kumala \& Siregar (2019) yang menyatakan bahwa CSR berpengaruh negatif terhadap manajemen laba serta mengungkapkan bahwa perusahaan yang memiliki kepedulian terhadap lingkungan dan stakeholder, cenderung mengungkapkan 
informasi keuangan secara transparan. Sehingga hal ini mempertegas bahwa perusahaan yang lebih berkomitmen dalam pengungkapan CSR memberikan pengungkapan keuangan yang lebih luas dan kurang terlibat dalam manajemen laba (Chih et al., 2008).

\subsection{Pengaruh Tanggung Jawab Sosial dan Kepemilikan Keluarga Terhadap Manajemen Laba}

Dalam hasil pengujian hipotesis diperoleh bahwa interaksi kepemilikan keluarga berpengaruh memperkuat hubungan negatif CSR terhadap manajemen laba. Hal ini menunjukkan melalui kepemilikan keluarga dapat membantu tanggung jawab sosial dalam meminimalisir manajemen laba. Hal tersebut dapat terjadi dikarenakan perusahaan keluarga cenderung untuk menajaga nama baik perusahaan dan keluarga melalui transparansi dalam laporan tahunan. Dalam hal ini, kepemilikan keluarga mempengaruhi hubungan kausal antara tanggung jawab sosial dan manajemen laba secara parsial dan bukan sebagai full moderating. Hal tersebut dapat terjadi karena dalam model 2 (dengan moderasi) tanggung jawab sosial masih berpangaruh signifikan terhadap manajemen laba. Sehubungan dengan itu, Kumala \& Siregar (2019) juga menyatakan bahwa kepemilikan keluarga memperkuat hubungan negatif antara CSR dan manajemen laba. Hal ini sejalan dengan penelitian Martínez-Ferrero et al. (2016) yang menyatakan bahwa adanya aspek kepemilikan keluarga akan mengurangi probabilitas adanya kebijaksanaan manajerial yang menyimpang seperti melakukan praktik manajemen. Dengan begitu, pengaruh keluarga dalam melakukan transparansi anggaran dan bentuk tanggung jawab dapat meminimalisir praktik manajemen laba.

Selain itu, hasil penelitian ini sejalan dengan Campopiano \& de Massis (2015) yang menyatakan bahwa keterlibatan kepemilikan keluarga memiliki peran yang penting terhadap pengungkapan CSR karena dapat menjaga nama baik perusahaan terhadap publik. Sehubungan dengan pendapat Kumala \& Siregar (2019) yang menyatakan bahwa pengawasan dan pengendalian atas kebijaksanaan manajerial sangat dipengaruhi oleh struktur kepemilikan, yang mana dalam perusahaan Indonesia didominasi oleh kepemilikan keluarga. Sehingga melalui kepemilikan keluarga dapat meminimalisir tindakan manajemen laba untuk tetap menjaga nama baik perusahaan dan lebih meningkatkan kepercayaan publik dengan mengungkapkan berbagai program CSR yang dilakukan perusahaan.

\section{SIMPULAN}

Berdasarkan hasil penelitian yang dilakukan, maka dapat disimpulkan bahwa tanggung jawab soaial aspek lingkungan berpengaruh negatif terhadap manajemen laba. Makin tinggi tingkat pengungkapan tanggung jawab sosial aspek lingkungan yang dilakukan perusahaan, makin rendah praktik manajemen laba yang dilakukan perusahaan manufajtur sektor barang dan konsumsi. Selanjutnya, kepemilikan keluarga terbukti memperkuat pengaruh negatif tanggung jawab sosial terhadap manajemen laba secara parsial. Temuan ini menunjukkan bahwa dengan adanya kepemilikan keluarga dalam perusahaan manufaktur sektor barang dan konsumsi akan semakin membatasi manajemen laba dan memilih untuk melakukan transparansi keuangan serta mengungkapkan tanggung jawab sosial dan lingkungan kepada seluruh pemangku kepentingan dalam rangka menjaga nama baik perusahaan dan keluarga.

Hasil penelitian ini menambah bukti empiris aplikasi teori stakeholder dalam konteks pengaruh CSR terhadap manajemen laba dengan kepemilikan keluarga sebagai pemoderasi perusahaan manufaktur sektor barang dan konsumsi. Hasil penelitian ini memperkuat teori stakeholder bahwa dengan adanya pengungkapan informasi melalui 
CSR, stakeholder akan disuguhkan dengan laporan keuangan yang transparan dengan minimnya praktik manajemen laba. Dengan begitu, melalui pengungkapan CSR dapat dijadikan strategi untuk memperkuat kepercayaan pemangku kepentingan terhadap perusahaan khususnya pada industri manufaktur sektor barang dan konsumsi milik keluarga di negara berkembang. Di samping itu, hasil penelitian ini juga dapat menjadi pertimbangan bagi investor dalam pengambilan keputusan investasi dengan memperhatikan pengungkapan CSR aspek lingkungan karena cenderung meminimalisir manajemen laba. Bagi regulator, yaitu Otoritas Jasa Keuangan (OJK) dan BapepamLK, dapat menjadi pertimbangan dalam menetapkan kebijakan khususnya aspek CSR karena belum semua perusahaan mampu dan dapat mentransparansikan tanggung jawab sosial aspek lingkungan dalam laporan tahunan. Sementara itu, saran yang dapat diberikan kepada perusahaan yaitu agar perusahaan tetap konsisten dan terus meningkatkan pengungkapan CSR aspek lingkungan agar dapat memperkuat kepercayaan pemangku kepentingan dan sebagai bentuk tanggung jawab terhadap sekitar khususnya lingkungan.

Keterbatasan dalam penelitian ini ialah untuk penentuan tingkat pengungkapan tanggung jawab sosial, penelitian ini hanya menggunakan laporan tahunan, tidak mengikutsertakan laporan berkelanjutan yang dilaporkan secara terpisah ataupun sumber informasi lainnya. Selain itu, adanya unsur subjektifitas peneliti dalam penilaian indikator variabel tanggung jawab sosial dalam penelitian ini. Dalam penentuan indikator kepemilikan keluarga, penelitian ini hanya berdasarkan persentase kepemilikan saham yang terdaftar di BEI, belum menggunakan informasi lain seperti kedudukan mayoritas keluarga dalam posisi dewan direksi atau dewan komisaris. Dengan adanya berbagai keterbatasan tersebut, terdapat beberapa saran yang berguna dalam penelitian selanjutnya. Pertama, menggunakan informasi lain selain laporan tahunan dalam menilai indikator tanggung jawab sosial, seperti menggunakan laporan berkelanjutan terpisah yang diterbitkan oleh perusahaan. Kedua, menggunakan informasi lain selain kepemilikan saham yang terdaftar di BEI dalam menentukan indikator kepemilikan keluarga, seperti melihat keikutsertaan keluarga dalam jajaran dewan direksi dan dewan komisaris perusahaan.

\section{REFERENSI}

Alonso, A. D., \& Austin, I. (2016). Entrepreneurial CSR in the context of a regional family firm: a stakeholder analysis. Annals in Social Responsibility, 2(1), 48-62.

https:// doi.org/10.1108/asr-06-20160005

Ambarwati, I. E., \& Stephanus, D. S. S. (2014). Struktur kepemilikan, kebijakan deividen, dan leverage sebagai determinan atas nilai perusahaan. Jurnal Akuntansi Multiparadigma, 5, 170-185.

Arieza, U. (2019). Menyoal laba BUMN yang mendadak kinclong. https://www.cnnindonesia.com/ekon omi/20190531144248-92400048/ menyoal-laba-bumn-yangmendadak-kinclong

Boermawan, C., \& Siregar, S. v. (2013). Hubungan stock split dengan manajemen laba pada perusahaan yang terdaftar di bursa efek Indonesia tahun 2001-2011. Jurnal Akuntansi Multiparadigma, 2(3), 1-9.

Campopiano, G., \& de Massis, A. (2015). Corporate social responsibility reporting: A content analysis in family and non-family firms. Journal of Business Ethics, 129(3), 511-534. https:// doi.org/10.1007/s10551-0142174-z 
Christoforus, R. (2019). Gelar aksi, aktivis dan ISM minta pemerintah perhatian pada perubahan iklim. https://nasional.kompas.com/read/2 019/09/20/17375641/gelar-aksiaktivis-dan-lsm-minta-pemerintahperhatian-pada-perubahan-iklim

Dianawati, W. (2017). Pengaruh karakteristik perusahaan dan sertifikasi lingkungan terhadap pengungkapan corporate social responsibility (CSR). EKUITAS (Jurnal Ekonomi Dan Keuangan), 20(2), 226.

https://doi.org/10.24034/j25485024.y2 016.v20.i2.1825

Globalreporting.org. (2016) GRI Standards. https://www.globalreporting.org/

Gujarati, D. N. (2012). Basic Econometrics (5th Editoi). McGraw -Hill Higher Education.

Gras-Gil, E., Palacios Manzano, M., \& Hernández Fernández, J. (2016). Investigating the relationship between corporate social responsibility and earnings management: Evidence from Spain. BRQ Business Research Quarterly, 19(4),

289-299. https://doi.org/10.1016/j.brq.2016.02. 002

Ibrahim, M., Solikahan, E. Z., \& Widyatama, A. (2015). Karakteristik perusahaan, luas pengungkapan corporate social responsibility, dan nilai perusahaan. Jurnal Akuntansi Multiparadigma. https://doi.org/10.18202/jamal.2015.0 4.6008

IDN Times Jateng. (2019). Ribuan pabrik manufaktur belum kelola limbah beracun, Kok bisa? https://jateng.idntimes.com/business /economy/fariz-fardianto/ribuanpabrik-manufaktur-belum-kelola- limbah-beracun-kok-bisa/3

Kim, Y., Park, M. S., \& Wier, B. (2012). Is earnings quality associated with corporate social responsibility? Accounting Review, 87(3), 761-796. https:// doi.org/10.2308/accr-10209

Kumala, R., \& Siregar, S. V. (2019). Corporate social responsibility, family ownership and earnings management: The case of Indonesia. Social Responsibility Journal. https:// doi.org/10.1108/SRJ-09-20160156

Kurniawati, H., \& Sudibyo, Y. A. (2017). Pengungkapan tanggung jawab sosial perusahaan dan economic value added: Peranan moderasi kepemilikan keluarga dan CSR award. Jurnal Keuangan Dan Perbankan, 14(1), 29-36.

Kusuma, Y. B. (2018). Perbedaan bisnis keluarga dengan non bisnis keluarga. https://binus.ac.id/malang/2018/06/ perbedaan-bisnis-keluarga-dengannon-bisnis-keluarga/

Liu, M., Shi, Y., Wilson, C., \& Wu, Z. (2017). Does family involvement explain why corporate social responsibility affects earnings management? Journal of Business Research, 75, 8-16. https://doi.org/10.1016/j.jbusres.2017 .02 .001

Mahiswari, R., \& Nugroho, P. I. (2016). Pengaruh mekanisme corporate governance, ukuran perusahaan dan leverage terhadap manajemen laba dan kinerja keuangan. Jurnal Ekonomi Dan Bisnis, 17(1), 1. https://doi.org/10.24914/jeb.v17i1.23 7

Majalah CSR. (2019). 5 hal yang meredefinisi sektor CSR di tahun 2019. https:// majalahcsr.id/5-hal-yangakan-meredefinisi-sektor-csr-di-tahun- 
2019/

Martínez-Ferrero, J., Banerjee, S., \& GarcíaSánchez, I. M. (2016). Corporate social responsibility as a strategic shield against costs of earnings management practices. Journal of Business Ethics, 133(2), 305-324. https://doi.org/10.1007/s10551-0142399-x

Martínez-Ferrero, J., Rodríguez-Ariza, L., \& García-Sánchez, I. M. (2016). Corporate social responsibility as an entrenchment strategy, with a focus on the implications of family ownership. Journal of Cleaner Production, 135, 760770.

https://doi.org/10.1016/j.jclepro.2016. 06.133

Muhajir Haris, A., \& Priyo Purnomo, E. (2016). Implementasi CSR (Corporate Social Responsibility) Pt. Agung Perdana dalam mengurangi dampak kerusakan lingkungan. Journal of Governance and Public Policy, 3(2), 203225.

https://doi.org/10.18196/jgpp.2016.00 56

Muttakin, M. B., Khan, A., \& Azim, M. I. (2015). Corporate social responsibility disclosures and earnings quality: Are they a reflection of managers' opportunistic behavior? Managerial Auditing Journal, 30(3), 277-298. https://doi.org/10.1108/MAJ-02-20140997

Nurcaya, I. A. H. (2020). Pengelolaan lingkungan, KLHK soroti sektor manufaktur.

https://ekonomi.bisnis.com/read/202 00209/257/1199097/pengelolaanlingkungan-klhk-soroti-sektormanufaktur

Octavia, E. (2017). Implikasi corporate governance dan ukuran perusahaan pada manajemen laba. Jurnal Akuntansi Multiparadigma, 204, 126-136. https://doi.org/10.18202/jamal.2017.0 4.7044

Perwitasari, D., Maret, U. S., \& Sutami, J. I. (2013). Struktur kepemilikan, karakteristik perusahaan, dan manajemen laba. Jurnal Akuntansi Multiparadigma, 5.

Salewski, M., \& Zülch, H. (2012). The impact of corporate social responsibility (CSR) on financial reporting quality evidence from european blue chips. SSRN Electronic Journal, 112, 2012. https:// doi.org/10.2139/ssrn.2141768

Santi, D. K., \& Wardani, D. K. (2018). Pengaruh tax planning, ukuran perusahaan, corporate social responsibility (CSR) terhadap manajemen laba. Jurnal Akuntansi, 6(1), $11-24$. https://doi.org/10.24964/ja.v6i1.536

Scholtens, B., \& Kang, F. (2012). Corporate social responsibility and earnings eanagement: Evidence from Asian economies. Corporate Social Responsibility and Evirontmental Management.

https:// doi.org/10.1002/csr.1286

Scott, W. R. (2012). Financial accounting theory. Canada: Prentice Hall.

Setyaningsih, R. D., \& Asyik, N. F. (2016). Pengaruh kinerja lingkungan terhadap kinerja keuangan dengan corporate social responsibility sebagai pemoderasi. Jurnal Ilmu Dan Riset Akuntansi, 5(4), 1-15.

Sokarina, A. (2012). Kualitas auditor, besaran transaksi antar pihak yang berhubungan istimewa dan manajemen laba. Jurnal Akuntansi 
Multiparadigma, 3(April).

https://doi.org/10.18202/jamal.2012.0

4.7142

Swat, A., Lindawati, L., \& Puspita, M. E. (2015). Corporate social responsibility: Implikasi stakeholder dan legitimacy gap dalam peningkatan kinerja perusahaan. Jurnal Akuntansi Multiparadigma, 6, 157-174. https://doi.org/10.18202/jamal.2015.0 4.6013

Villarón-Peramato, O., García-Sánchez, I. M., \& Martínez-Ferrero, J. (2018). Capital structure as a control mechanism of a CSR entrenchment strategy. European Business Review, 30(3), 340-371. https://doi.org/10.1108/EBR-03-20170056

Wirawan, A. W., Falah, L. J., Adhariani, D., Djakman, C. D., Wirawan, A. W., Falah, L. J., \& Kusumadewi, L. (2020). The effect of corporate social responsibility on the firm value with risk management as a moderating variable the effect of corporate social responsibility on the firm value with risk Management as a moderating variable. Journal of Asia-Pacific Business, 21(2). https://doi.org/10.1080/10599231.202 0.1745051 